\title{
Peningkatan Kemampuan Mengenal Konsep Lambang Bilangan 1 - 10 Melalui Permainan Pohon Hitung pada Anak Usia 4 - 5 Tahun di BKB PAUD Harapan Bangsa
}

\author{
Ockti Syafitri $^{1}$, Rohita $^{2}$, Nila Fitria ${ }^{3}$ \\ ${ }^{1,2,3}$ Program Studi Pendidikan Guru Pendidikan Anak Usia Dini, Fakultas Psikologi dan Pendidikan, \\ Universitas Al Azhar Indonesia, Jl. Sisingamangaraja, Kebayoran Baru, Jakarta Selatan, 12110.
}

Penulis untuk Korespondensi/E-mail: Ocktisyafitri@gmail.com

Abstrak - Perkembangan kognitif merupakan aspek yang penting dalam mengembangkan kemampuan berpikir anak, salah satunya yaitu mengenal konsep lambang bilangan. Penelitian ini bertujuan untuk mengetahui bagaimana peningkatan kemampuan mengenal konsep lambang bilangan 1 - 10 melalui permainan pohon hitung pada anak usia $4-5$ tahun di BKB PAUD Harapan Bangsa. Penelitian ini merupakan Penelitian Tindakan Kelas (PTK) yang menggunakan model Kemmis dan Mc Taggart yang dilakukan selama 2 siklus, di mana satu siklus terdiri dari 3 kali pertemuan. Subjek penelitian ini adalah 14 anak, yang terdiri dari 9 anak laki-laki dan 5 anak perempuan. Teknik pengumpulan data yang digunakan dalam penelitian ini adalah observasi kemampuan anak dalam mengenal konsep lambang bilangan 1 10, aktivitas guru dan anak serta dokumentasi. Teknik analisis data yang digunakan pada penelitian ini adalah deskriptif kualitatif dengan menggunakan perhitungan statistika sederhana. Berdasarkan hasil penelitian diketahui bahwa terdapat peningkatan dalam kemampuan mengenal konsep lambang bilangan 1 - 10 melalui permainan pohon hitung. Hal ini diketahui dari rata-rata anak yang mendapat skor 3 pada setiap indikator yaitu indikator membilang 1 - 10 siklus I sebesar 69,1\% dan siklus II sebesar $100 \%$ artinya terdapat peningkatan sebesar $30,9 \%$. Pada indikator menghubungkan benda-benda konkret dengan lambang bilangan 1 - 10 siklus I sebesar 55,4\% dan siklus II sebesar 77,6\% artinya terdapat peningkatan sebesar $22,2 \%$ dan pada indikator mengurutkan lambang bilangan 1 - 10 siklus I $\mathbf{4 4 , 7 \%}$ dan siklus II sebesar $\mathbf{7 7 , 6 \%}$ artinya terdapat peningkatan sebesar 32,9\%. Pencapaian di siklus II sudah melebihi indikator keberhasilan yang telah ditentukan yaitu sebesar $75 \%$. Berdasarkan hasil penelitian dapat disimpulkan bahwa permainan pohon hitung dapat meningkatkan kemampuan mengenal konsep lambang bilangan 1 - 10. Peningkatan terjadi karena dalam penelitian ini dilakukan melalui permainan dengan menggunakan media pohon hitung yang beracuan pada teori mengenai tahapan-tahapan mengenal lambang bilangan kepada anak dan dengan adanya motivasi berupa reward membuat anak lebih semangat dalam melakukan permainan.

Kata Kunci - Mengenal Konsep Lambang Bilangan, Permainan Pohon Hitung, Anak Usia 4 -5 Tahun

Abstract - Cognitive development is an important aspect in developing children's thinking skills, one of which is to recognize the concept of numeral symbol. This study aims to find out how to improve the ability to recognize the concept of numeral symbol 1 - 10 through tree math game at the children aged 4 - 5 years of BKB PAUD Harapan Bangsa. This study is a classroom action research (CAR) using Kemmis and Mc Taggart model carried out in 2 cycles where one cycle consists of 3 meetings. The subjects of this study are 14 children, 9 of them are boys and the rest are girls. Data collection technique used in this study is observation towards the ability of children in recognizing the concept of numeral symbol $1-10$, the teacher as well as the children activities and documentation. Data analysis technique used in this study is descriptive 
qualitative using simple statistical calculation. According to the research results it is known that there is an improvement in the ability to recognize the concept of numeral symbol 1 - 10 through the tree math game. It can be seen from the average of children who got score 3 on each indicator which is counting $1-10$ in cycle $I$ is as much as $69,1 \%$ and in cycle II rises to $100 \%$. It means that there is an increase of $30,9 \%$. While on the indicator of connecting concrete objects with numeral symbols of $1-10$ in cycles $I$ show the average of $55.4 \%$ and in the second cycle rise to $77.6 \%$ which means there is an increase of $22.2 \%$. Furthermore, on the indicator of sorting numeral symbol of $1-10$ in cycle I show the average of $44.7 \%$ and in cycle II climb to $\mathbf{7 7 . 6 \%}$ which means there is an increase of $32.9 \%$. Therefore, the achievement in cycle II has exceeded the predetermined success indicator of $75 \%$. Based on the research results it can be concluded that the tree math game can improve the ability of children aged 4-5 years to recognize the concept of numeral symbol $1-10$. The improvement occurs because this study is carried out through the game using the tree math media which refers to the theory of the stages of knowing numeral symbol to the children and with the motivation in the form of reward to make them more enthusiastic in playing the game.

Keywords - Knowing the Concept of Numeral Symbol, Tree Math Game, Children Aged 4 - 5 Years.

\section{PENDAHULUAN}

\section{Latar Belakang Masalah}

Salah satu aspek yang harus dikembangkan Suru TK sebagai pendidik di sekolah pada anak usia dini adalah aspek perkembangan kognitif. Perkembangan kognitif merupakan aspek perkembangan yang penting dalam mengembangkan kemampuan berpikir anak. Menurut PERMENDIKBUD RI Nomor 137 Tahun 2014 tentang Standar Nasional Pendidikan Anak Usia Dini terdapat 8 macam standar, salah satunya adalah standar isi. Pada standar isi di dalamnya ada tingkat pencapaian perkembangan anak yang diantaranya mengenai lingkup perkembangan kognitif dari berbagai macam kelompok usia. [1]

Lingkup perkembangan kognitif untuk anak usia $4-5$ tahun terbagi menjadi tiga yaitu belajar dan pemecahan masalah, berpikir logis serta berpikir simbolik. Kemampuan berpikir simbolik untuk anak usia $4-5$ tahun yaitu anak mampu untuk membilang banyak benda satu sampai sepuluh, mengenal konsep bilangan dan mengenal lambang bilangan. Sementara, di dalam PERMENDIKBUD Nomor 146 Tahun 2014 diketahui pula terdapat indikator berpikir simbolik yang menyatakan bahwa anak mampu menghubungkan benda-benda konkret dengan lambang bilangan $1-10$. [2]

Terkait dengan judul penelitian yaitu peningkatan kemampuan mengenal konsep lambang bilangan $1-10$ melalui permainan pohon hitung pada anak usia $4-5$ tahun, kemampuan ini sangatlah penting bagi anak usia dini. Kemampuan mengenal konsep lambang bilangan dapat mengembangkan keterampilan berpikir, menalar, dan memecahkan masalah. Hal ini dikarenakan dalam kehidupan sehari-harinya, anak terlibat langsung dalam penggunaan lambang bilangan sebagai contoh ketika anak membilang benda, saat anak merapikan mainannya, membaca lambang bilangan atau angka pada jam sehingga anak mengetahui waktunya, ditanya tentang usia dan anak mampu menyebutkan angkanya, menghitung jarak yang ditempuh misalnya dari rumah ke sekolah, bermain jual beli sehingga anak mampu membaca angka/nominal yang tertera pada uang, mengetahui nomor rumah dan lain-lain.

Melihat pentingnya mengenal konsep lambang bilangan, maka guru memiliki peran penting dalam memberikan stimulasi yang sesuai dengan kebutuhan dan perkembangan anak. Dengan demikian, guru perlu mengetahui tentang karakteristik layanan pendidikan anak usia dini di mana dalam pembelajaran sebagai guru harus dapat memahami prinsip-prinsip yang digunakan dalam proses pembelajaran anak usia dini. Menurut PERMENDIKBUD RI Nomor 137 Tahun 2014, prinsip-prinsip tersebut yaitu belajar melalui bermain, berorientasi pada perkembangan anak, berorientasi pada kebutuhan anak, berpusat pada anak, pembelajaran aktif, berorientasi pada pengembangan nilai-nilai karakter, berorientasi pada pengembangan kecakapan hidup, didukung oleh lingkungan yang 
kondusif, berorientasi pada pembelajaran yang demokratis, pemanfaatan media belajar, sumber belajar, dan narasumber penggunaan media belajar, sumber belajar, dan narasumber yang ada di lingkungan PAUD. [1]

Berdasarkan hasil observasi, diskusi dengan salah satu guru BKB PAUD Harapan Bangsa dan tes kemampuan mengenal konsep lambang bilangan yang dilakukan pada tanggal $30-31$ Maret 2017, diperoleh informasi bahwa dari 14 anak diketahui 11 anak masih memiliki kemampuan yang rendah dalam mengenal konsep lambang bilangan. Sebagian besar dari jumlah anak sudah mampu dalam membilang/menyebutkan $1-10$, tetapi anak belum mampu memahami dengan benar konsep dan simbol/ lambang bilangan tersebut. Data yang diperoleh melalui tes kemampuan mengenal konsep lambang bilangan menggunakan media kartu angka dan stik es krim yaitu, dalam kemampuan membilang 1 10 sekitar 7 anak (64\%) sudah mampu membilang dengan benar dan tidak ragu-ragu sedangkan terdapat 4 anak (36\%) masih raguragu, tertukar dan juga lupa setelah angka 7 ke angka selanjutnya. Kemudian, dalam kemampuan menghubungkan benda-benda konkret dengan lambang bilangan $1-10$ terdapat 4 anak (36\%) yang sudah mampu menghubungkan benda-benda konkret dengan lambang bilangan $1-10$, terdapat $1(9 \%)$ anak masih tampak ragu-ragu dan bingung. Sedangkan, terdapat $6(55 \%)$ anak lainnya masih belum mampu dalam menghubungkan benda-benda konkret dengan lambang bilangan. Lalu, ketika diminta untuk menyusun/mengurutkan kartu angka $1-10$ terdapat 3 anak (27\%) sudah mampu dalam mengurutkan lambang bilangan dengan benar, terdapat 1 anak (9\%) yang masih kurang mampu dalam mengurutkan, sedangkan 7 anak lainnya (64\%) masih belum mampu dalam mengurutkan.

Berdasarkan pengamatan, penulis melihat banyak faktor yang menjadi penyebab rendahnya kemampuan anak dalam mengenal konsep lambang bilangan $1-10$ diantaranya adalah kurang mampunya guru dalam memanfaatkan penggunaan media dan alat peraga pembelajaran. Alat bantu pembelajaran yang tersedia di sekolah untuk mengenalkan konsep lambang bilangan hanya terdiri dari poster angka dan papan tulis, tetapi selama ini guru lebih sering menggunakan papan tulis dalam mengenalkan konsep lambang bilangan kepada anak. Metode pembelajaran yang diterapkan guru pun kurang bervariatif. Dalam mengenalkan konsep lambang bilangan, guru lebih sering menggunakan metode pembelajaran tanya jawab dan ceramah dalam bentuk klasikal. Selain itu, kurang menariknya kegiatan pembelajaran yang guru berikan dalam mengenalkan konsep lambang bilangan pada anak misalnya mewarnai gambar angka, menebalkan angka pada garis putus-putus, menulis lambang bilangan di papan tulis dan menjodohkan jumlah benda dengan lambang bilangan pada Lembar Aktivitas Anak.

Sejalan dengan pernyataan di atas, untuk mengoptimalkan tujuan pembelajaran dalam meningkatkan kemampuan mengenal konsep lambang bilangan kepada anak usia dini, diperlukannya metode, media maupun kegiatan pembelajaran yang menarik minat anak. Melalui metode, media dan kegiatan pembelajaran yang menyenangkan dan menarik minat anak, diharapkan pembelajaran tersebut dapat berjalan secara kondusif, tidak menimbulkan rasa jenuh, bosan dan rasa terpaksa dalam diri anak. Salah satu alternatif/ solusi yang dapat membantu dalam meningkatkan kemampuan mengenal konsep lambang bilangan pada anak adalah melalui permainan pohon hitung. Permainan adalah salah satu cara untuk membuat kegiatan pembelajaran lebih menarik, menyenangkan dan dilakukan oleh anak secara sukarela.

Dalam permainan tersebut, media pembelajaran yang akan digunakan adalah pohon hitung. Pohon hitung merupakan suatu media pembelajaran yang berbentuk pohon, dilengkapi dengan kantong dan kartu angka berbentuk buah-buahan yang dapat dilepaspasangkan. Media pohon hitung ini akan dibuat dengan memodifikasi pohon hitung yang saat ini sudah ada agar lebih sesuai dengan tujuan pembelajaran. Media pohon hitung ini akan dibuat oleh guru dengan menggunakan bahanbahan yaitu triplek, bord, kardus bekas, kardus susu bekas ukuran $250 \mathrm{ml}$, mika, stik es krim, pot, perekat dan kain flanel.

Berdasarkan uraian di atas dan mengingat pentingnya mengenal konsep lambang bilangan pada anak usia 4 - 5 tahun, maka akan dilakukan penelitian yang berjudul 
"Peningkatan Kemampuan Mengenal Konsep Lambang Bilangan 1 - 10 melalui Permainan Pohon Hitung pada Anak Usia 4 - 5 Tahun di BKB PAUD Harapan Bangsa".

\section{Identifikasi Masalah}

Berdasarkan latar belakang masalah di atas, maka identifikasi masalah dalam penelitian ini adalah sebagai berikut:

1. Kurang tepatnya metode atau cara mengajar yang digunakan guru mengakibatkan masih rendahnya kemampuan anak dalam mengenal konsep lambang bilangan.

2. Berbagai metode dapat digunakan guru untuk meningkatkan kemampuan mengenal konsep lambang bilangan.

3. Permainan-permainan yang menarik dapat meningkatkan kemampuan mengenal konsep lambang bilangan.

4. Rendahnya kemampuan guru dalam menggunakan dan memanfaatkan media pembelajaran mengakibatkan materi pembelajaran yang diberikan kurang tersampaikan dengan optimal, sehingga anak masih sulit dalam memahami pembelajaran.

5. Rendahnya media pembelajaran yang tersedia di kelas mengakibatkan guru dituntut untuk lebih kreatif dalam membuat media pembelajaran.

6. Kurang menariknya kegiatan pembelajaran bagi anak mengakibatkan pembelajaran mengenal konsep lambang bilangan menjadi kurang bermakna.

\section{Pembatasan Masalah}

Berdasarkan identifikasi masalah di atas, maka pembatasan masalah dalam penelitian ini difokuskan pada permainan pohon hitung untuk meningkatkan kemampuan mengenal konsep lambang bilangan 1 - 10 pada anak usia $4-5$ tahun di BKB PAUD Harapan Bangsa.

\section{Rumusan Masalah}

Berdasarkan latar belakang dan pembatasan masalah di atas, maka rumusan masalah dalam penilitian ini adalah "Bagaimana Peningkatan Kemampuan Mengenal Konsep Lambang Bilangan 1 - 10 melalui Permainan Pohon Hitung pada Anak Usia 4 - 5 di BKB PAUD Harapan Bangsa?".

\section{Tujuan Penelitian}

Penelitian ini bertujuan untuk meningkatkan kemampuan mengenal konsep lambang bilangan $1-10$ melalui permainan pohon hitung pada anak usia $4-5$ di BKB PAUD Harapan Bangsa.

\section{Manfaat Penelitian}

1. Bagi Guru

a. Memberikan masukan kepada guru dalam menggunakan serta menerapkan permainan alternatif yaitu pohon hitung dalam meningkatkan kemampuan mengenal konsep lambang bilangan pada anak usia $4-5$ tahun sehingga dapat menarik minat anak dalam pembelajaran.

b. Mempermudah guru dalam memberikan materi pembelajaran kepada anak dalam meningkatkan mengenal konsep lambang bilangan melalui permainan pohon hitung.

2. Bagi Kepala Sekolah

Memberikan masukan kepada kepala sekolah tentang penggunaan metode dan media yang menyenangkan untuk meningkatkan kemampuan anak dalam mengenal konsep lambang bilangan melalui permainan pohon hitung sehingga tujuan pembelajaran dapat tercapai secara optimal.

\section{Bagi Peneliti}

Penelitian ini akan memberikan manfaat yaitu pengalaman praktis dalam bidang penelitian ilmiah dan dapat mengetahui peningkatan kemampuan mengenal konsep lambang bilangan melalui permainan pohon hitung.

\section{KAJIAN TEORI}

\section{Kemampuan Mengenal Konsep Lambang Bilangan Anak Usia 4 - 5 Tahun}

1. Pengertian Lambang

Ismunamto, dkk (2011: 24) simbol atau lambang digunakan untuk mewakili suatu bilangan disebut angka atau lambang bilangan [3]. Sedangkan Rosdiani, dkk (2014: Vol 2) lambang merupakan visualisasi dari berbagai konsep, misalnya lambang 7 untuk menggambarkan konsep bilangan tujuh, merah untuk 
menggambarkan konsep warna, besar untuk menggambarkan konsep ruang, dan persegi empat untuk menggambarkan konsep bentuk [4]. Jadi, lambang dapat dikatakan sebagai suatu simbol yang mewakili dari suatu konsep yang ada seperti contoh konsep bilangan dua dilambangkan dalam angka 2 dan kesesuaian jumlah benda misalnya 2 apel dapat dilambangkan dengan lambang bilangan 2 .

\section{Pengertian Bilangan}

Ismunamto, dkk (2011: 24) menyatakan bahwa bilangan adalah suatu konsep matematika yang digunakan untuk pencacahan dan pengukuran [3]. Sejalan dengan itu, menurut Suyono (dalam Rosdiani dkk, 2014: Vol 2) bilangan merupakan suatu angka kumpulan yang diukur satuan [4]. Pendapat lain tentang bilangan menurut Harnett \& Gelman (dalam Seefeldt \& Barbara A. Wasik, 2008: 392) kepekaan bilangan itu mencakup pengembangan rasa kuantitas dan pemahaman kesesuaian satu lawan satu [5]. Sedangkan, dalam Handoyo (2011: 38) makna dari suatu angka atau bilangan dapat diketahui dari simbol atau lambang bilangan serta operasi hitungnya [6].

Berdasarkan pendapat di atas, dapat disimpulkan bahwa lambang bilangan adalah simbol/ lambang yang digunakan untuk menuliskan nama bilangan dan biasanya dilambangkan melalui angka (1, 2, 3, 4, 5, 6, 7, dan sebagainya).

3. Tahap Mengenal Lambang Bilangan

Menurut Burns (dalam Mutiah, 2010: 161 - 162) mengatakan kelompok matematika yang sudah dapat diperkenalkan mulai dari usia tiga tahun adalah kelompok bilangan (aritmatika, berhitung), pola dan fungsinya, geometri, ukuran-ukuran, grafik estimasi, probabilitas, pemecahan masalah [7]. Penguasaan masing-masing kelompok melalui tiga tahapan, yaitu:
a. Tingkat pemahaman konsep
b. Tingkat menghubungkan konsep konkret dengan lambang bilangan
c. Tingkat lambang bilangan

4. Ruang Lingkup Kemampuan Mengenal Konsep Lambang Bilangan Anak Usia 4 5 Tahun

Kemampuan berpikir simbolik untuk anak usia $4-5$ tahun menurut PERMENDIKBUD RI Nomor 137 Tahun 2014 tentang Standar Nasional Pendidikan Anak Usia Dini, yaitu anak mampu membilang banyak benda satu sampai sepuluh, mengenal konsep bilangan, mengenal lambang bilangan [1]. Sementara, di dalam PERMENDIKBUD Nomor 146 Tahun 2014 diketahui pula terdapat indikator berpikir simbolik yang menyatakan bahwa anak mampu menghubungkan benda-benda konkret dengan lambang bilangan $1-10$ [2].

\section{Permainan Pohon Hitung}

1. Pengertian Permainan

Menurut Piaget (dalam Desmita, 2009: 142) menyatakan bahwa ia percaya struktur-struktur kognitif anak perlu dilatih, dan permainan merupakan setting yang sempurna bagi latihan ini [8]. Melalui permainan memungkinkan anakanak mengembangkan kompetensikompetensi dan keterampilanketerampilan yang diperlukannya dengan cara yang menyenangkan. Hal ini senada dengan pendapat Vygotsky (dalam Mutiah, 2010: 138), yang menyatakan bahwa permainan adalah suatu setting yang bagus bagi perkembangan kognitif ia tertarik khususnya pada aspek-aspek simbolis dan khayalan suatu permainan [7].

2. Jenis-jenis Permainan

Mutiah (2010: 139) beberapa jenis permainan, yaitu:

a. Permainan sensorimotor, yaitu perilaku yang diperlihatkan bayi untuk memperoleh kenikmatan dari melatih perkembangan (skema) sensorimotor mereka.

b. Permainan praktis, yaitu melibatkan pengulangan perilaku keterampilanketerampilan baru sedang dipelajari. Permainan ini utamanya muncul pada bayi, sedangkan permainan praktis terjadi sepanjang hayat.

c. Permainan pura-pura (simbolis), yaitu terjadi ketika anak mentransformasikan 
lingkungan fisik ke dalam suatu simbol.

d. Permainan sosial, yaitu permainan yang melibatkan interaksi sosial dengan teman sebaya.

e. Permainan fungsional, yaitu permainan pertama yang dilakukan pada awal masa anak-anak, di mana anak mengulang-ulang kegiatan sederhana dan menemukan kesenangan dalam bermain dengan lingkungannya. Permainan ini berguna untuk meningkatkan motorik anak.

f. Permainan konstruktif, yaitu terjadi ketika anak-anak melibatkan diri dalam suatu kreasi atau konstruksi suatu produk atau pemecahan masalah ciptaan sendiri.

g. Game, yaitu kegiatan-kegiatan yang dilakukan untuk memperoleh kenikmatan yang melibatkan aturan dan sering kali bersifat kompetisi. [7]

\section{Pengertian Pohon Hitung}

Menurut Lely (dalam Rosdiani dkk, 2014: Vol 2) juga mengemukakan bahwa media pohon bilangan dengan istilah lain pohon hitung adalah alat peraga pembelajaran berbentuk seperti pohon dengan kartu angka yang dibentuk seperti buahbuahan/bujur sangkar/lingkaran, yang dapat dikreasikan oleh guru sesuai tema pembelajaran [4].

Berdasarkan pendapat di atas, dapat disimpulkan bahwa pohon hitung adalah suatu media atau alat peraga edukatif yang berbentuk pohon disertai dengan kartu angka yang berbentuk buah-buahan. Melalui media pohon hitung ini dapat mempermudah guru dalam memberikan materi pembelajaran kepada anak seperti berhitung, mengenal angka, dan mengenal bentuk angka dengan menggunakan metode bermain sesuai dengan prinsip pembelajaran anak usia dini. Selain itu, mengenalkan konsep lambang bilangan melalui permainan pohon hitung akan lebih bermakna dan menyenangkan bagi anak.

Permainan pohon hitung pada penelitian ini dibuat dan dimainkan sesuai dengan tahapan mengenal lambang bilangan. Di mana cara permainannya yaitu pertama- tama anak diperintahkan untuk berdiri di garis start kemudian anak diperintahkan untuk melompati lingkaran yang sudah diberi tanda lambang bilangan sambil membilang (1, 2, 3, 4 dan 5) setelah itu anak diminta untuk berjalan zig-zag sambil membilang $(6,7,8,9$ dan 10). Lalu, anak diminta untuk berlari menuju pohon hitung. Setelah itu, anak diminta untuk menghitung jumlah stik es krim yang telah disusun acak oleh guru pada tiap-tiap kantong pohon hitung. Kemudian, anak diminta untuk menempelkan kartu angka sesuai dengan jumlah stik es krim pada kantong yang telah disusun acak. Setelah itu, anak diminta untuk menyusun urutan lambang bilangan yang benar pada papan flanel yang telah disediakan. Kemudian, dilanjutkan dengan anak selanjutnya.

\section{Kerangka Berpikir}

Melihat pentingnya mengenal konsep lambang bilangan bagi anak, maka guru memiliki peran penting dalam memberikan stimulasi yang sesuai dengan kebutuhan dan perkembangan anak. Untuk itu, dalam mengenalkan konsep lambang bilangan harus dilakukan dengan cara bertahap. Tahap pertama adalah tahap konsep, yaitu tahap utama sebelum anak mengenal lambang. Pada tahap ini, biasanya anak akan melakukan kegiatan bermain seperti menghitung benda yang dilihatnya atau berada di sekitarnya. Tahap kedua adalah tahap transmisi/ tingkat menghubungkan konsep konkret dengan lambang bilangan yaitu anak sudah benar-benar memahami tahap konsep. Pada tahap ini anak mulai diajarkan tentang lambang bilangan dan anak sudah mengetahui kesesuaian jumlah benda dengan lambang bilangan yang mewakilinya. Tahap ketiga adalah tahap lambang, yaitu tahap terakhir setelah anak sudah melewati tahap-tahap sebelumnya. Berdasarkan ketiga tahap tersebut, maka indikator kemampuan mengenal konsep lambang bilangan yang ditentukan dalam penelitian ini adalah membilang/menyebutkan, menghubungkan benda-benda konkret dengan lambang 
bilangan dan mengurutkan lambang bilangan $1-10$.

\section{METODOLOGI PENELITIAN}

\section{Jenis Penelitian}

Menurut Kemmis dan Mc. Taggart (dalam Kunandar, 2009: 42 - 43), penelitian tindakan adalah suatu bentuk self-inquiry kolektif yang dilakukan oleh para partisipan di dalam situasi sosial untuk meningkatkan rasionalitas dan keadilan dari praktik sosial atau pendidikan yang mereka lakukan, serta mempertinggi pemahaman mereka terhadap praktik dan situasi di mana praktik itu dilaksanakan [9].

\section{Tempat Penelitian}

Penelitian Tindakan Kelas ini dilaksanakan di BKB PAUD Harapan Bangsa yang terletak di Jl. H Khair RT 06 RW 004, Kelurahan Ragunan. Alasan penulis memilih BKB PAUD Harapan Bangsa, karena penulis mengamati terdapat suatu masalah yang terjadi di dalam kelas yaitu masih rendahnya kemampuan anak usia $4-5$ tahun dalam mengenal konsep lambang bilangan $1-10$ dan belum pernah diterapkannya permainan pohon hitung dalam mengenalkan konsep lambang bilangan $1-10$ kepada anak.

\section{Waktu Penelitian}

Penelitian Tindakan Kelas ini dilaksanakan pada bulan Maret - Juni Tahun Ajaran 2016 2017. Penelitian ini dilakukan selama dua siklus di mana setiap siklus terdapat tiga kali pertemuan. Sehingga dapat dikatakan penelitian ini dilakukan sebanyak enam kali sampai dengan siklus ke dua.

\section{Subjek Penelitian}

Subjek dalam penelitian ini adalah anak Kelompok A2 yang berusia $4-5$ tahun di BKB PAUD Harapan Bangsa Tahun Ajaran 2016 2017 berjumlah 14 anak yang terdiri dari 9 anak laki-laki dan 5 anak perempuan.

\section{Desain Penelitian}

Dalam perencanaannya Kemmis (dalam Sukidin, dkk, 2010: 48 - 49) menggunakan sistem spiral refleksi diri yang dimulai dengan rencana, tindakan, pengamatan, refleksi dan perencanaan kembali yang merupakan dasar untuk suatu ancang-ancang pemecahan permasalahan [10].

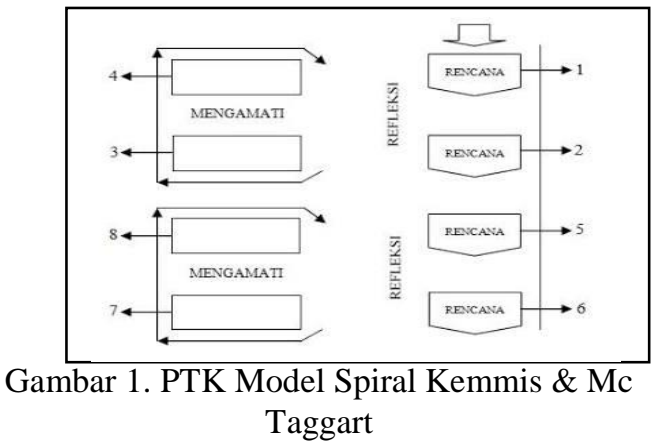

\section{Prosedur Penelitian}

Berdasarkan uraian desain penelitian di atas, maka prosedur atau langkah-langkah dalam penelitian ini diuraikan sebagai berikut:

1. Tahapan Perencanaan (Planning)

2. Tahapan Pelaksanaan Tindakan

3. Tahapan Observasi

4. Tahapan Refleksi (Reflection)

\section{Teknik Pengumpulan Data}

Teknik pengumpulan data merupakan cara peneliti untuk memperoleh data. Untuk memperoleh data peneliti membuat instrumen penelitian. Teknik pengumpulan data dari penelitian ini adalah:

1. Observasi/ pengamatan

Pedoman observasi yang digunakan sebagai instrumen penelitian ini adalah lembar observasi tentang indikator pembelajaran peningkatan kemampuan mengenal konsep lambang bilangan 1-10 pada anak usia 4 - 5 tahun berdasarkan tahap kemampuan mengenal konsep lambang bilangan pada anak kelompok A2 (usia $4-5$ tahun) yaitu membilang/ menyebutkan, menghubungkan bendabenda konkret dengan lambang bilangan dan mengurutkan lambang bilangan $1-10$ pada saat proses pembelajaran dengan memberi check list. Selain itu, dalam penelitian ini peneliti juga menggunakan lembar observasi guru dan anak untuk mengamati aktivitas guru dan anak selama proses KBM.

2. Dokumentasi/foto

Adapun dalam penelitian ini dokumentasi digunakan sebagai penguat data. Dokumentasi dalam penelitian ini adalah berupa foto yang diambil berdasarkan proses pembelajaran anak. 


\section{Instrumen Penelitian}

Instrumen yang digunakan dalam penelitian ini adalah lembar observasi tentang peningkatan kemampuan mengenal konsep lambang bilangan pada anak usia $4-5$ tahun dengan menggunakan permainan pohon hitung, aktivitas anak dalam proses permainan pohon hitung, dan juga aktivitas guru dalam memberikan kegiatan pembelajaran.

\section{Teknik Analisis Data}

Data yang telah terkumpul akan dianalisis menggunakan teknik analisis deskriptif kualitatif untuk menggambarkan kondisi atau suasana pembelajaran baik dari guru maupun anak dan perhitungan statistik sederhana untuk mengukur skor/presentase keberhasilan kemampuan anak dalam mengenal konsep lambang bilangan $1-10$. Dengan demikian dapat diketahui sejauh mana peningkatan kemampuan anak dalam mengenal konsep lambang bilangan yang telah dicapai setelah distimulasi menggunakan permainan pohon hitung.

\section{Indikator Keberhasilan Penelitian}

Kriteria keberhasilan dalam penelitian ini adalah apabila minimal $75 \%$ dari total jumlah anak sudah mampu mengenal konsep lambang bilangan $1-10$ atau masing-masing indikator penilaian mendapatkan skor 3 maka dinyatakan berhasil. Kriteria keberhasilan anak dalam mengenal konsep lambang bilangan $1-10$ dapat disimpulkan pada tabel berikut:

\begin{tabular}{cc}
\multicolumn{2}{c}{ Tabel 1. Kriteria Ketuntasan } \\
\hline $\begin{array}{cc}\text { Presentase } \\
\text { Ketuntasan }\end{array}$ & Klasifikasi \\
\hline$>80$ & Sangat baik \\
$>60-80$ & Baik \\
$>40-60$ & Cukup \\
$>20-40$ & Kurang \\
$\leq 20$ & Sangat \\
& Kurang \\
\hline
\end{tabular}

(Sumber: Widoyoko, 2015: 242)

Data yang dianalisa dalam persentase menggunakan rumus:

$$
\mathrm{P}=\frac{\mathrm{F}}{\mathrm{N}} \times 100 \%
$$

(Sumber: Marliza, 2012)

Keterangan:

$\mathrm{P}=$ Angka Presentasi

$\mathrm{F}=$ Frekuensi aktivitas/skor anak

$\mathrm{N}=$ Jumlah anak dalam satu kelas

\section{HASIL DAN PEMBAHASAN}

\section{Hasil Penelitian}

1. Temuan Umum

BKB PAUD Harapan Bangsa adalah PAUD yang terletak di Jl. H Khair RT 006 RW 04, Kelurahan Ragunan, Kecamatan Pasar Minggu. BKB PAUD Harapan Bangsa berdiri sejak tahun 2009 karena inisiatif dari ibu-ibu PKK untuk memberikan pendidikan pada anak usia dini khususnya disekitar lingkungan RW 04 Kelurahan Ragunan. BKB PAUD Harapan Bangsa memiliki luas bangunan $36 \mathrm{~m}^{2}$. BKB PAUD Harapan Bangsa terletak di antara mushola dan pemukiman warga.

2. Temuan Khusus

Penelitian Tindakan Kelas (PTK) ini dilaksanakan menjadi dua siklus, di mana masing-masing siklus terdiri dari tiga kali pertemuan. Indikator yang akan dinilai pada penelitian ini adalah kemampuan anak dalam membilang $1-10$, menghubungkan benda-benda konkret dengan lambang bilangan $1-10$ dan mengurutkan lambang bilangan $1-10$ melalui permainan pohon hitung.

a. Siklus I

\section{1) Perencanaan}

Tahap perencanaan, peneliti membuat persiapan pembelajaran yang akan dilakukan pada siklus I. Peneliti mendiskusikan tema pembelajaran dan mempersiapkan Rencana Pelaksanaan Pembelajaran Harian (RPPH) bersama dengan guru kelas. Kemudian, peneliti mempersiapkan media pembelajaran yang akan digunakan dalam mengenalkan konsep lambang bilangan $1-10$, menyiapkan lembar observasi kemampuan mengenal konsep lambang bilangan 1 10, lembar observasi aktivitas guru dan anak, reward yang akan diberikan untuk memotivasi anak dan kamera handphone untuk mendokumentasikan kegiatan pembelajaran.

\section{2) Pelaksanaan Tindakan}

Melaksanakan tindakan sesuai dengan apa yang telah direncanakan. 


\section{3) Observasi}

a) Hasil pengamatan kemampuan anak dalam mengenal konsep lambang bilangan $1-10$ pada siklus I diuraikan melalui diagram berikut ini:

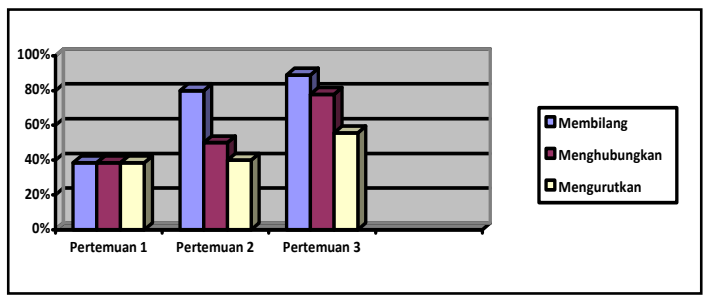

Gambar 2. Diagram Kemampuan Mengenal Konsep Lambang Bilangan 1 - 10 pada Siklus I b) Hasil pengamatan aktivitas guru dan anak pada saat proses pembelajaran disiklus I diuraikan melalui diagram dan tabel berikut ini:

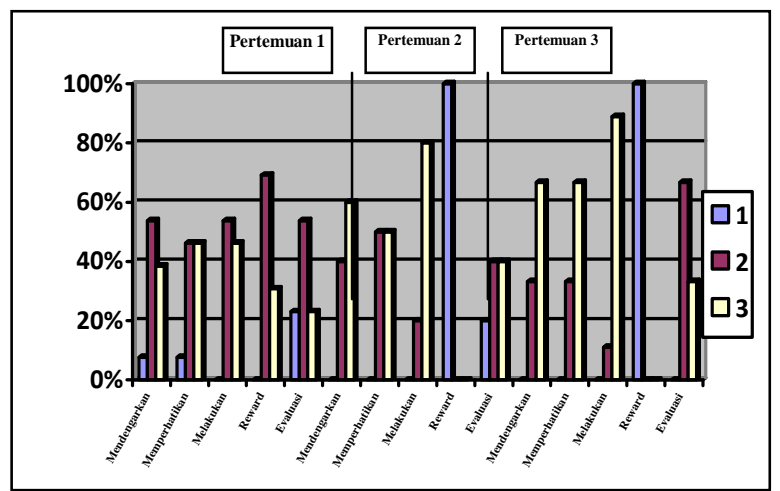

Gambar 3.Diagram Observasi Aktivitas Anak pada Siklus I

Tabel 2. Rekapitulasi Observasi Aktivitas Guru Siklus I

\begin{tabular}{|c|c|c|c|c|c|c|c|c|c|c|c|c|c|c|c|}
\hline \multirow[t]{3}{*}{ Siklus I } & & $\begin{array}{l}\text { njelas } \\
\text { Tujua } \\
\text { rmai }\end{array}$ & & $\begin{array}{r}\mathrm{M} \\
\mathrm{C} \\
\text { Pern }\end{array}$ & $\begin{array}{l}\text { mber } \\
\text { toh C } \\
\text { inan } \\
\text { Hitun }\end{array}$ & $\begin{array}{l}\text { In } \\
\text { ra } \\
\text { hon }\end{array}$ & \multicolumn{3}{|c|}{$\begin{array}{l}\text { Mengamati dan } \\
\text { Membantu Anak } \\
\text { Ketika sedang } \\
\text { Melakukan } \\
\text { Permainan Pohon }\end{array}$} & \multicolumn{3}{|c|}{$\begin{array}{c}\text { Memberikan } \\
\text { Reward kepada } \\
\text { Anak }\end{array}$} & \multicolumn{3}{|c|}{$\begin{array}{c}\text { Melakukan } \\
\text { Evaluasi }\end{array}$} \\
\hline & \multicolumn{3}{|c|}{ Skor } & \multicolumn{3}{|c|}{ Skor } & \multicolumn{3}{|c|}{ Skor } & \multicolumn{3}{|c|}{ Skor } & \multicolumn{3}{|c|}{ Skor } \\
\hline & $\mathrm{k}$ & $\mathrm{c}$ & $\mathrm{b}$ & $\mathrm{k}$ & $\mathrm{c}$ & $\mathrm{b}$ & $\mathrm{k}$ & $\mathrm{c}$ & $\mathrm{b}$ & $\mathrm{k}$ & $\mathrm{c}$ & $\mathrm{b}$ & $\mathrm{k}$ & $\mathrm{c}$ & B \\
\hline Pert 1 & & & $\sqrt{ }$ & & & $\sqrt{ }$ & & & $\sqrt{ }$ & & $\sqrt{ }$ & & & & $\sqrt{ }$ \\
\hline Pert 2 & & & $\sqrt{ }$ & & $\sqrt{ }$ & & & & $\sqrt{ }$ & $\sqrt{ }$ & & & & & $\sqrt{ }$ \\
\hline Pert 3 & & & $\sqrt{ }$ & & & $\sqrt{ }$ & & & $\sqrt{ }$ & $\sqrt{ }$ & & & & $\sqrt{ }$ & \\
\hline
\end{tabular}

\section{4) Refleksi Tindakan Siklus I}

Hasil pengamatan penelitian pada siklus I menunjukkan bahwa indikator keberhasilan belum tercapai. Berdasarkan hasil pengamatan dan diskusi oleh peneliti, guru dan teman sejawat, diperoleh hal-hal yang menjadi penghambat pada siklus I, antara lain:

a) Suara guru kurang lantang

b) Ketika guru menjelaskan dan mencontohkan permainan pohon hitung pada saat membilang sambil melompat serta berjalan zig-zag, meja yang diletakkan di depan anak menutupinya sehingga beberapa anak harus berdiri untuk melihat contoh permainan yang dijelaskan oleh guru.

c) Guru terlalu cepat dalam mencontohkan permainan pohon hitung.

d) Guru kurang menjelaskan tujuan dari diberikannya reward kepada anak.
Reward yang diberikan guru sebaiknya dalam berbagai variasi.

e) Beberapa anak masih kurang memahami apa yang harus dilaksanakan dalam permainan pohon hitung sehingga masih harus dibimbing dan dibantu oleh guru.

f) Permainan pohon hitung dilakukan di dalam kelas bersamaan dengan anak yang sedang melakukan kegiatan lain sehingga menyebabkan pembelajaran kurang kondusif karena terdapat sebagian anak yang masih mengobrol, bercanda, berjalan-jalan, memberi tahu teman yang sedang bermain pohon hitung dan anak yang sedang bermain pohon hitung menjadi kurang leluasa.

g) Kegiatan permainan pohon hitung terlalu panjang sehingga anak yang belum mendapatkan giliran jadi menunggu lama. Selain itu, setiap anak unik terdapat anak yang dengan mudah atau cepat menerima dan melakukan 
pembelajaran serta terdapat anak yang masih lambat.

h) Beberapa anak terlihat masih ragu-ragu dan takut salah saat membilang, menghubungkan dan mengurutkan lambang bilangan $1-10$ padahal beberapa anak sudah mengetahui atau sudah mengerti.

i) Ketika kegiatan menghitung stik es krim, terdapat anak yang masih tidak mau mengeluarkan stik es krim untuk dihitung satu-satu.

j) Ketika anak menyusun urutan lambang bilangan terdapat anak yang kesulitan mencari kartu angka karena kartu angka yang guru sediakan terlalu banyak.

k) Anak tidak mengerti tujuan diberikannya reward oleh guru.

\section{b. $\quad \underline{\text { Siklus II }}$}

1) Perencanaan

a) Guru disarankan untuk melantangkan suara, agar seluruh anak dapat mendengarkannya.

b) Agar seluruh anak dapat melihat contoh cara permainan pohon hitung dengan jelas dan lebih leluasa, guru mengubah tempat pelaksanaan permainan pohon hitung yaitu menjadi di luar kelas dengan memanggil 4 anak secara bergantian untuk melakukan permainan pohon hitung, sedangkan anak yang lainnya diminta tetap di dalam kelas untuk mengerjakan kegiatan lain yang telah direncanakan guru.

c) Guru menjelaskan dan mencontohkan permainan dengan perlahan-lahan atau secara detail agar anak lebih memahami cara permainannya dan tidak ragu-ragu lagi.

d) Pada saat guru mencontohkan permainan pohon hitung, guru sebaiknya melibatkan seluruh anak untuk mencoba secara langsung dengan memanggil anak bergantian e) Guru merubah cara pelaksanaan permainan pohon hitung.

f) Guru mengganti reward stiker bintang menjadi wafer tango dan top.

\section{2) Pelaksanaan Tindakan}

Melaksanakan tindakan sesuai dengan apa yang telah direncanakan.

3) Observasi

a) Hasil pengamatan kemampuan anak dalam mengenal konsep lambang bilangan 1 - 10 pada siklus I diuraikan melalui diagram berikut ini:

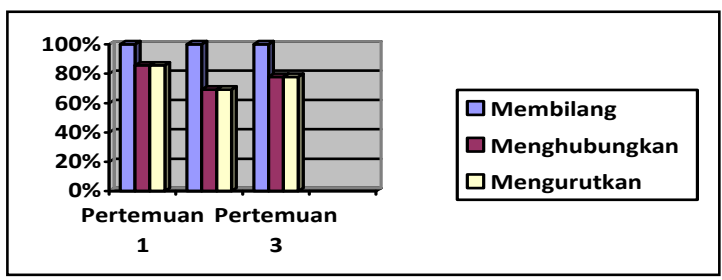

Gambar 4. Diagram Kemampuan Mengenal Konsep Lambang Bilangan 1 - 10 pada Siklus II

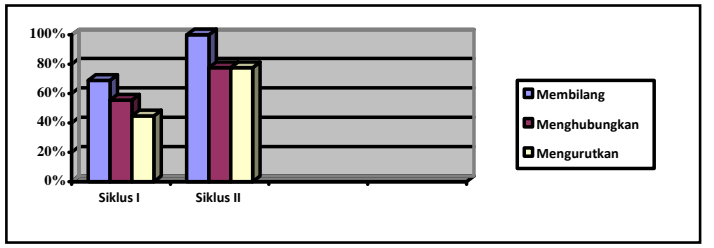

Gambar 5. Diagram Presentase Peningkatan Setiap Siklus

b) Hasil pengamatan aktivitas guru dan anak pada saat proses pembelajaran disiklus I diuraikan melalui diagram dan tabel berikut ini:

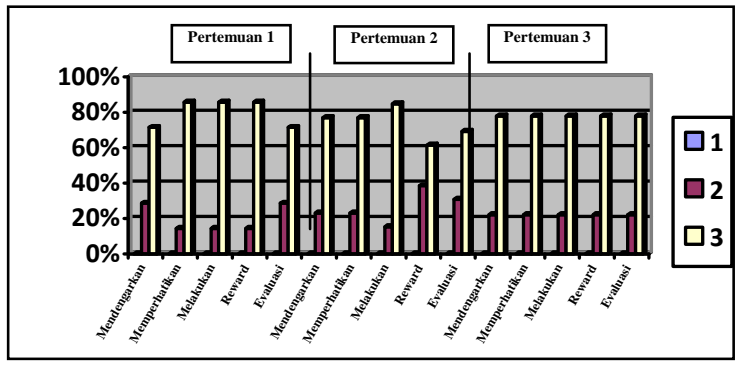

Gambar 6. Diagram Observasi Aktivitas Anak pada Siklus II 
Tabel 3. Rekapitulasi Observasi Aktivitas Guru pada Siklus II

\begin{tabular}{|c|c|c|c|c|c|c|c|c|c|c|c|c|c|c|c|}
\hline \multirow{3}{*}{ Siklus II } & \multicolumn{15}{|c|}{ Mengamati dan } \\
\hline & \multicolumn{3}{|c|}{$\begin{array}{l}\text { Menjelaskan } \\
\text { Tujuan } \\
\text { Permainan }\end{array}$} & \multicolumn{3}{|c|}{$\begin{array}{c}\text { Memberikan } \\
\text { Contoh Cara } \\
\text { Permainan Pohon } \\
\text { Hitung }\end{array}$} & \multicolumn{3}{|c|}{$\begin{array}{c}\text { Membantu Anak } \\
\text { Ketika sedang } \\
\text { Melakukan } \\
\text { Permainan Pohon } \\
\text { Hitung } \\
\end{array}$} & \multicolumn{3}{|c|}{$\begin{array}{c}\text { Memberikan } \\
\text { reward kepada } \\
\text { anak }\end{array}$} & \multicolumn{3}{|c|}{$\begin{array}{c}\text { Melakukan } \\
\text { evaluasi }\end{array}$} \\
\hline & $\mathrm{k}$ & $\mathrm{c}$ & $\mathrm{b}$ & $\mathrm{k}$ & $\mathrm{c}$ & $\mathrm{B}$ & $\mathrm{k}$ & $\mathrm{c}$ & $\mathrm{b}$ & $\mathrm{k}$ & $\mathrm{c}$ & b & $\mathrm{k}$ & c & b \\
\hline Pert 1 & & & $\sqrt{ }$ & & & $\sqrt{ }$ & & & $\sqrt{ }$ & & & $\sqrt{ }$ & & & $\sqrt{ }$ \\
\hline Pert 2 & & & $\sqrt{ }$ & & & $\sqrt{ }$ & & & $\sqrt{ }$ & & $\sqrt{ }$ & & & & $\sqrt{ }$ \\
\hline Pert 3 & & & $\sqrt{ }$ & & & $\sqrt{ }$ & & & $\sqrt{ }$ & & & $\sqrt{ }$ & & & $\sqrt{ }$ \\
\hline
\end{tabular}

\section{4) Refleksi}

Berdasarkan hasil observasi, maka refleksi siklus II yaitu didapatkan hasil bahwa terdapat peningkatan pada kemampuan mengenal konsep lambang bilangan $1-10$, aktivitas anak dan guru. Tindakan pada siklus II telah mencapai indikator keberhasilan penelitian, sehingga peneliti menghentikan penelitian ini pada siklus II karena sudah mencapai indikator keberhasilan yang telah ditetapkan.

\section{PEMBAHASAN}

Berdasarkan data yang diperoleh pada siklus II, dapat dikatakan bahwa tindakan yang dilakukan telah berhasil karena nilai yang diperoleh anak sudah melebihi target yang telah ditentukan pada indikator keberhasilan yaitu sebesar $75 \%$. Ketercapaian ini diperoleh karena dalam mengenalkan konsep lambang bilangan 1 - 10 dilakukan dengan kegiatan permainan pohon hitung.

Melalui permainan pohon hitung dapat mempermudah anak dalam mengenal konsep lambang bilangan baik membilang, menghubungkan dan mengurutkan lambang bilangan $1-10$. Sebagaimana yang telah dijelaskan oleh Tresnawati (dalam Wati 2015: Vol 3) bahwa media pohon hitung merupakan media yang jenisnya visual. Media pohon hitung adalah mainan edukasi untuk melatih kemampuan anak [11]. Adapun manfaat dari pohon hitung yaitu untuk melatih kemampuan kognitif anak seperti berhitung, mengenal angka dan mengenal bentuk angka.
Kemudian, faktor lain yang mendukung meningkatnya kemampuan mengenal konsep lambang bilangan $1-10$ juga dikarenakan adanya reward yang diberikan guru sehingga membuat anak menjadi semangat dan senang dalam mengikuti kegiatan permainan pohon hitung.

Faktor lain yang juga mendukung meningkatnya kemampuan mengenal konsep lambang bilangan 1 - 10 dikarenakan langkahlangkah yang dilakukan dalam permainan pohon hitung sesuai dengan tahapan mengenal lambang bilangan yaitu pertama-tama anak diminta untuk membilang benda-benda konkret, selanjutnya anak memasuki masa peralihan dari konkret ke lambang di mana anak mampu untuk menghubungkan jumlah benda-benda konkret dengan lambang bilangan yang mewakilkan jumlah benda tersebut, setelah itu anak memasuki tahap lambang. Sebagaimana yang telah dijelaskan oleh Burns (dalam Mutiah, 2010: 161 - 162) mengatakan bahwa kelompok matematika yang sudah dapat diperkenalkan mulai dari usia tiga tahun adalah kelompok bilangan (aritmatika, berhitung), pola dan fungsinya, geometri, ukuran-ukuran, grafik estimasi, probabilitas, pemecahan masalah. Penugasan masing-masing kelompok melalui tiga tahapan yaitu tingkat pemahaman, tingkat menghubungkan konsep konkret dengan lambang bilangan dan tingkat lambang bilangan [7].

Apabila dikaitkan dengan aspek perkembangan lainnya, permainan pohon hitung bukan hanya dapat mengembangkan dan melatih perkembangan kognitif saja tetapi juga mempengaruhi aspek perkembangan lainnya yaitu seperti aspek perkembangan sosial 
emosional, fisik motorik, bahasa, moral agama dan seni. Pada aspek perkembangan sosial emosional, anak dilatih untuk bersabar, mengantri menunggu giliran dan anak mau bermain bersama teman. Melalui permainan pohon hitung ini juga dapat melatih fisik motorik anak, baik itu motorik halus maupun motorik kasar karena langkah-langkah yang dilakukan dalam permainan pohon hitung terdapat kegiatan berlari, melompat, berjalan zig-zag dan juga menempel kartu angka pada papan flanel serta pohon hitung.

Selain itu, pada aspek perkembangan bahasa dapat melatih anak untuk melaksanakan kegiatan sesuai dengan arahan dan perintah sederhana yang diberikan guru serta membilang/menyatakan bilangan $1-10$. Kemudian pada perkembangan moral dan agama, anak mengetahui bahwa pohon dan buah-buahan merupakan ciptaan Allah serta mengajarkan anak untuk dapat menyanyangi dan merawat tumbuhan. Selanjutnya, pada aspek perkembangan seni adalah ketika anak diminta untuk bernyanyi bersama tentang lambang bilangan $1-10$.

\section{KESIMPULAN DAN SARAN}

\section{Kesimpulan}

Berdasarkan hasil data yang diperoleh dapat disimpulkan bahwa terdapat peningkatan dalam kemampuan mengenal konsep lambang bilangan 1 - 10 ketika sebelum dan sesudah diterapkannya kegiatan permainan pohon hitung pada anak usia $4-5$ tahun di BKB PAUD Harapan Bangsa. Nilai peningkatan rata-rata anak yang mendapat skor 3 pada setiap indikator persiklus dari siklus I ke siklus II pada indikator membilang 1 - 10 siklus I sebesar $69,1 \%$ dan siklus II sebesar $100 \%$ artinya terdapat peningkatan sebesar $30,9 \%$, pada indikator menghubungkan benda-benda konkret dengan lambang bilangan $1-10$ siklus I sebesar $55,4 \%$ dan siklus II sebesar $77,6 \%$ artinya terdapat peningkatan sebesar $22,2 \%$ dan pada indikator mengurutkan lambang bilangan 1 - 10 siklus I 44,7\% dan siklus II sebesar $77,6 \%$ artinya terdapat peningkatan sebesar $32,9 \%$.

Terjadinya peningkatan tersebut, dikarenakan dalam mengenalkan konsep lambang bilangan dilakukan dengan melalui permainan pohon hitung yang sebelumnya belum pernah diterapkan dalam mengenalkan konsep lambang bilangan kepada anak. Selain itu, dalam merencanakan permainan pohon hitung tersebut peneliti beracuan pada teori mengenai tahapan-tahapan mengenal lambang bilangan kepada anak yaitu melalui tingkat pemahaman, tingkat menghubungkan konsep konkret dengan lambang bilangan dan tingkat lambang bilangan. Peningkatan juga terjadi karena adanya motivasi berupa reward yang membuat anak lebih semangat dalam melakukan permainan pohon hitung.

Selain itu, melalui permainan pohon hitung juga dapat melatih dan mengembangkan aspek perkembangan anak yang lainnya, sehingga dapat disimpulkan bahwa permainan pohon hitung merupakan kegiatan yang terintegratif karena berpengaruh pada seluruh aspek perkembangan seperti sosial emosional, fisik motorik, bahasa, moral agama dan seni.

\section{Saran}

Berdasarkan hasil penelitian tersebut, peneliti memberikan beberapa saran, diantaranya:

1. Bagi Guru

a. Sebaiknya dalam melaksanakan permainan pohon hitung dikaitkan dengan tema pembelajaran.

b. Sebaiknya dalam menerapkan permainan pohon hitung dilakukan di luar kelas dengan memanggil anak secara bergantian agar anak lebih leluasa dalam melakukan permainan.

c. Kartu angka yang disediakan guru dalam kegiatan mengurutkan lambang bilangan sebaiknya tidak telalu banyak, misalnya cukup satu sampai dua set.

d. Sebaiknya dalam mengevaluasi pembelajaran, suara guru dapat lebih lantang agar anak mau mendengarkannya.

e. Reward yang diberikan untuk anak sebaiknya lebih bervariasi sesuai dengan kesukaan anak misalnya makanan seperti wafer.

f. Guru hendaknya memberikan pemahaman kepada orang tua maupun anak agar lebih semangat untuk datang ke sekolah. 
2. Bagi Kepala Sekolah

Kepala sekolah hendaknya mendukung kemampuan mengenal konsep lambang bilangan anak dengan menyediakan media pembelajaran yang bervariasi, misalnya pohon hitung.

\section{DAFTAR PUSTAKA}

[1] PERMENDIKBUD RI NO 137 Tahun 2014 Tentang Standar Nasional Pendidikan Anak Usia Dini.

[2] PERMENDIKBUD RI NO 146 Tahun 2014.

[3] Ismunamto, A. 2011. Ensiklopedia Matematika 1. Jakarta : Lentera Abadi.

[4] Rosdiani, Luh Putu Dian, dkk. 2014. "Penerapan Think Pair Share Berbantuan Media Pohon Bilangan untuk Meningkatkan Kemampuan Mengenal Lambang Bilangan Anak". eJournal PG-PAUD Universitas Pendidikan Ganesha Jurusan Pendidikan Guru Pendidikan Anak Usia Dini. Volume $2 . \quad$ No 1. http://ejournal.undiksha.ac.id/index.php/J JPAUD/article/view/3094 (diakses tanggal 13 Januari 2017).

[5] Seefeldt, Carol dan Barbara A. Wasik. 2008. Pendidikan Anak Usia Dini Menyiapkan Anak Usia Tiga, Empat dan Lima Tahun Masuk Sekolah. Jakarta : PT Indeks.

[6] Handoyo, Bekti Hermawan. 2011. Membuat Anak Gemar \& Pintar Matematika. Jakarta : Transmedia Pustaka.
[7] Mutiah, Diana. 2010. Psikologi Bermain Anak Usia Dini. Jakarta : Kencana.

[8] Desmita. 2009. Psikologi Perkembangan. Bandung : PT Remaja Rosdakarya.

[9] Kunandar. 2009. Langkah Mudah Penelitian Tindakan Kelas Sebagai Pengembangan Profesi Guru. Jakarta : PT Rajagrafindo Persada.

[10] Sukidin, dkk. 2010. Manajemen Penelitian Tindakan Kelas. Banten : Insan Cendekia.

[11] Wati, Anak A, dkk. 2015. "Penerapan Metode Pemberian Tugas Berbantuan Media Pohon Hitung untuk Meningkatkan Perkembangan Kognitif Anak Kelompok B1. e-Journal PG-PAUD Universitas Pendidikan Ganesha Jurusan Pendidikan Guru Pendidikan Anak Usia Dini. Volume 3. No 1. http://ejournal.undiksha.ac.id/index.php/J JPAUD/article/view/6016 (diakses tanggal 13 Januari 2017).

[12] Departemen Pendidikan Nasional. 2007. Permainan Behitung Permulaan di Taman Kanak-Kanak. Jakarta.

[13] Marliza. 2012. "Peningkatan Kemampuan Motorik Halus Anak Melalui Permainan Melukis dengan Kuas Taman Kanak-Kanak Pasaman Barat”. Jurnal Pesona PAUD Vol 1 No 1.

[14] Suyono dan Hariyanto. 2015. Belajar dan Pembelajaran. Bandung : PT Rosdakarya.

[15] Widoyoko, Eko Putro. 2015. Evaluasi Program Pembelajaran Panduan Praktis bagi Pendidik dan Calon Pendidik. Yogyakarta : Pustaka Pelajar. 